\title{
PREVALENCE OF BOVINE TUBERCULOSIS IN CATTLE IN THE SELECTED UPAZILA OF SIRAJGANJ DISTRICT IN BANGLADESH
}

\author{
M. A. A. Mahmud ${ }^{1 *}$, S. M. S. H. Belal ${ }^{2}$ and N. Z. Shoshe ${ }^{3}$ \\ ${ }^{1}$ Additional Veterinary Surgeon, Upazila Livestock Office, Ullapara, Sirajganj \\ ${ }^{2}$ Veterinary Surgeon, District Veterinary Hospital, Sirajganj, ${ }^{3}$ Department of Livestock Production and \\ Management, Sylhet Agricultural University, Sylhet, Bangladesh
}

\begin{abstract}
A study was conducted to ascertain the prevalence of Bovine tuberculosis at 135 commercial dairy farms of five upazilas of Sirajganj district of Bangladesh during the period from January 2012 to December 2013. During two years study period a total of 270 blood samples were tested by Antigen ${ }^{\circledR}$ Rapid Bovine TB Ab test kit. The overall prevalence of bovine tuberculosis was recorded as $7.78 \%$. Distribution on the basis of age, sex and breed revealed the significant relationship among the infection, breed, sex and age in the population. The prevalence was relatively high in older cattle $(10.23 \%)$ and the highest prevalence was observed in the female $(9.09 \%)$. The prevalence of tuberculosis infection was considerably high in most of large herds. It was evident from the study that cattle were infected with organism and caused a serious economic loss.
\end{abstract}

Key words: Prevalence, Bovine tuberculosis, Sirajganj district, Antigen ${ }^{\circledR}$ Test Kit

\section{INTRODUCTION}

Livestock plays an important role in the economy of the country. Human life is highly associated with livestock population in the different livestock production system (Bekele et al., 2010). But the sector is continuously facing some threats; Bovine tuberculosis (bTB) is one of them. The bTB is a chronic contagious debilitating disease of animals associated with progressive weakness/emaciation and tubercle (granuloma) formation, mainly confined to respiratory system (primarily in the lungs) and occasionally in other organs (Menzies and Neill, 2000). The infection to bovine can occur through the colostrums/milk to calves, ingestion of feed contaminated with feces of infected animals, aerosol, contact with each other and other wildlife (Polyakov et al., 1994). The causative agent of tuberculosis (Mycobacterium) can remain viable in the environment/soil for about two years (Hutchings and Harris, 1997). This highly-adapted and 'successful' pathogen has a world-wide distribution and in several countries bovine TB remains a major, costly infectious disease of cattle and other domesticated, feral and wild animal populations (Pollock and Neill, 2002; Mathews et al., 2006; Carslake et al., 2011). It has been recognized from 176 countries as one of the important bovine diseases causing great economic loss (Hines et al., 1995; Martin et al., 1994; Samad, 2008). This disease not only poses a threat to the economy of developing countries but also remains a problem in developed world (Khan et al., 2008). This disease has public health importance and is of great significance to international trade of animals and animal products (OIE, 2004). One billion people are infected with the tubercle bacillus, and there are eight million new cases and three million deaths annually (Samad, 2008). In the Indian subcontinent, the prevalence of bTB varies in different parts and during different months of the year (Khan et al., 2008). The prevalence of bTB in cattle has been reported as 5.9\% and 3.05\% in Pabna and Mymensingh district respectively (Pharo et al., 1981; Samad and Rahman, 1986) while, in breeding bull it is reported as $27.5 \%$ (Islam et al., 2007). The prevalence of bTB in Red Chittagong cattle observed as 30\% (Rahman and Samad, 2008). Mandal (2012) observed that the overall prevalence of bovine tuberculosis was 5.9\% at sadar upazila of Mymensingh district which was examined by Antigen Rapid Bovine TB Ab test kit. The study showed 33.73\% prevalence of bTB by Caudal Fold Tuberculin Test (CFT) in Rangpur division of Bangladesh (Tahmid Uddin et al., 2014). Although the density of cattle population is high in Sirajganj district but most of the previous studies on bTB have been carried out nationally, and do not provide adequate epidemiological picture of the disease in this area. Considering the above facts, we designed a study to know the prevalence of bovine tuberculosis in cattle of Sirajganj district as measured by the Antigen Rapid Bovine TB AbTest Kit.

*Corresponding e-mail address: dr.mahmud04@gmail.com

Copyright ( 2014 Bangladesh Society for Veterinary Medicine

All rights reserved 0302/2014 


\section{A. A. Mahmud and others}

\section{MATERIALS AND METHODS \\ Location and duration of study}

Five upazilas of Sirajganj district namely Sirajganj Sadar, Shahjadpur, Ullapara, Kamarkhand and Belkuchi were selected on the basis of number and size the herds. Three administrative union from each upazila and three villages from each union were taken for this study. The study was conducted over a period of 24 months during January 2012 to December 2013.

\section{Animal selection and sample collection}

Three herds from each village and two cattle of over 6 months old from each herd were selected for the study. About $10 \mathrm{ml}$ of whole blood sample was collected from the jugular vein, using plain vaccutainer tubes and needles from each cattle aged above six and with no history of vaccination for tuberculosis. Each sample tube was labeled using codes specific to the individual sample. The tubes were tilted and serum was collected either passively by decanting or after centrifugation of the blood samples at $2,500 \mathrm{rpm}$ for 5 minutes. The serum was stored at $-20^{\circ} \mathrm{C}$ until tested serologically.

\section{Rapid kit test (Immuno chromatographic assay)}

The samples were subjected to Antigen ${ }^{\circledR}$ Rapid Bovine tuberculosis Antibody Test Kit (Immuno chromatographic assay) for the detection of TB antibodies. For this, Ten $\mu$ l (one drop) serum was added to the sample hole marked " $\mathrm{S}$ " on the test device with a capillary tube or single cannel micro titer pipette and waited for 1 minute and then added 3 drops of the developing buffer into the developing buffer hole. Appearance of a purple band in the result window of the test kit within 20 minutes indicates positive result (Fig. 1) and indicating control band only in negative result. In positive cases, intensity of the faint purple band appeared within 20 minutes. No result was read after 20 minutes.

\section{Statistical analysis}

Data were entered in Microsoft Excel 2007 and transferred to R 2.14.2 (The R Foundation for Statistical Computing, Vienna, Austria). Descriptive statistics were obtained using Data Mining package of the software $\mathrm{R}$ 2.14.2.

\section{RESULTS AND DISCUSSION}

In this study 270 cattle of different age, sex and breeds in 135 commercial dairy farms in Sirajganj district of Bangladesh were examined to determine the potential infection of tuberculosis by Antigen Rapid bTB Ab test kit. Results indicate that the overall prevalence of bovine tuberculosis was $7.78 \%$ in study area. But in some cases the prevalence was found to vary in some upazilas. The highest rate was found in Shahjadpur and Ullapara upazila $(9.26 \%)$ and the lowest was found in kamarkhand upazila (5.56\%). Sirajganj Sadar and Belkuchi also constituted an equal and significant prevalence (7.41\%) (Table 1). The prevalence obtained in this study was found relating to the stock density in different upazila (Report of DLS and statistical pocket book, 2011). High number of cattle population in Shahjadpur upazila favored the transmission of organism among animals probably causing high prevalence. Prevalence of bovine tuberculosis observed in the study area was $5.41 \%$ in the younger stock (6 months to 2 years of age) which was increasing with the advance of age and reached as much as $10.23 \%$ (above 6 years of age) which was shown in table 2. Animals younger than 6 months were not included in this study because of lacking report of occurrence in this age group. Variation in the prevalence was also observed with sex. Female reported a comparatively higher prevalence than the male. The prevalence of tuberculosis, regardless of the upazila, in male and female was 5.71\% and 9.09\% respectively (Table 2). All crossbreed animals including our indigenous cattle are found susceptible to tuberculosis, but carried a variation in the prevalence which was higher in local breed (13.33\%). The prevalence of Holstein Frisian $\times$ Local cross breed was $(7.51 \%)$ but the prevalence was found almost similar (Table 2) in SindhixLocal cross breed (5.00\%), and Sahiwal $\times$ Local cross breed $(5.71 \%)$.

Bovine tuberculosis (bTB) is one of the most prevalent economically important zoonotic diseases, known to exist in all over the world including Bangladesh. An overall prevalence of bovine tuberculosis in the study area was $7.78 \%$ which was comparable with the reports of Pharo et al. (1981), Samad and Rahman (1986). But, it was 
lower than the reports of Rahman and Samad (2008), Ameni et al. (2007), Islam et al. (2007) and Swai et al. (2006).

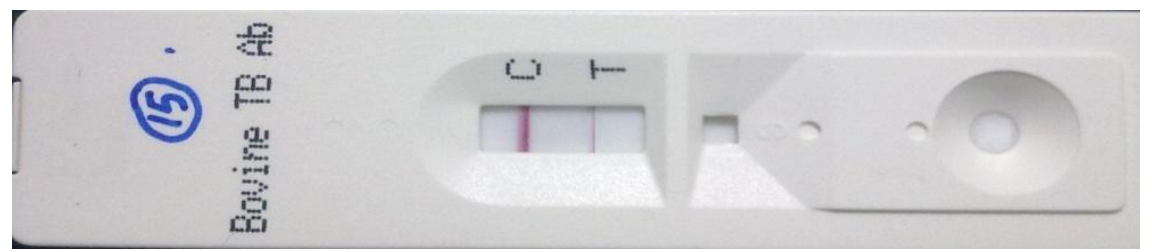

Fig. 1. Bovine TB Ab test positive

Table 1. Distribution of tuberculosis in cattle in different areas of Sirajganj district

\begin{tabular}{|c|c|c|c|c|c|}
\hline Upazila & $\begin{array}{l}\text { Number } \\
\text { Union }\end{array}$ & of & $\begin{array}{l}\text { No. of cattle } \\
\text { tested }\end{array}$ & $\begin{array}{l}\text { Number of positive } \\
\text { case }\end{array}$ & Prevalence $(\%)$ \\
\hline SirajganjSadar & 03 & & 54 & 04 & 7.41 \\
\hline Shahjadpur & 03 & & 54 & 05 & 9.26 \\
\hline Ullapara & 03 & & 54 & 05 & 9.26 \\
\hline Kamarkhand & 03 & & 54 & 03 & 5.56 \\
\hline Belkuchi & 03 & & 54 & 04 & 7.41 \\
\hline Overall & 15 & & 270 & 21 & 7.78 \\
\hline
\end{tabular}

Table 2. Age, sex and breed-wise prevalence of tuberculosis in cattle

\begin{tabular}{lllll}
\hline Groups & Factors & Tested & Positive & Prevalence (\%) \\
\hline \multirow{5}{*}{ Age group } & \multicolumn{1}{c}{6 months-2 yrs. } & 74 & 4 & 5.41 \\
& $>2-6$ yrs. & 108 & 8 & 7.41 \\
& Above 6 yrs. & 88 & 9 & 10.23 \\
Gender & Overall & 270 & 21 & 7.78 \\
& Male & 105 & 6 & 5.71 \\
& Female & 165 & 15 & 9.09 \\
& Overall & 270 & 21 & 7.78 \\
Breed & Local & 60 & 8 & 13.33 \\
& HF $\times$ L & 80 & 6 & 7.50 \\
& SL $\times$ L & 70 & 4 & 5.71 \\
& S $\times$ L & 60 & 3 & 5.00 \\
& Overall & 270 & 21 & 7.78 \\
\hline
\end{tabular}

Local=Indigenous cattle, HF = Holstein-Friesian, SL = Sahiwal, S = Sindhi, L= Local cattle

Prevalence of bovine tuberculosis is influenced by many factors such as geographical situation of a country, and its temperature, hygienic status of humans and animals and enforced regulatory laws in Public Health and Veterinary Public Health sectors. The differences also may be due to size of the sample, type of diagnostic test used, husbandry system etc. History of coughing was found significantly associated with bovine tuberculosis which is in agreement with Sauter and Morris (1995). The prevalence obtained in this study represents area of high cattle density where there are chances of intermixing during free grazing in the field (bathan). The farmers of this area were accustomed to an extensive system of management, keeping both healthy and infected animals together under purely traditional systems and providing less nutritious feed which made animals highly susceptible to diseases like brucellosis and tuberculosis (Adesokan et al., 2006). Adult cattle over the age of 6 years had the highest prevalence (10.23\%). Cleave land et al. (2007) and Phillips et al. (2002) suggested that older animals are more susceptible to tuberculosis. It suggests that as the animal becomes older, the chance of it becoming infected increases. As the animals live for a longer period on the farm, they might have a greater possibility of contact with the infectious agent. The male to female infection ratios recorded over the years where females were found more susceptible to tuberculosis (Table 2). Different breeds of cattle demonstrated different 


\section{A. A. Mahmud and others}

prevalence (Table 2). Approximately $48 \%$ of the variation seen in response to infection with $M$. bovis is due to host genetic variation (Griffin and Mackintosh, 2000). The prevalence of local breed was highest (13.33\%) among all crossbreed (Table 2). The study was supported by Tahmid Uddin et al. (2014), where he reported that local breed was the most susceptible to tuberculosis. Holstein cattle showed higher skin test prevalence and disease severity compared to their zebu herd-mates (Vordermeier et al., 2011). The findings had also demonstrated significant heritability to susceptibility to bovine TB in Holstein cattle (Birmingham al., 2009). In conclusion, therefore, for the control and eradication of tuberculosis in cattle population, more attention should be paid towards separation of healthy and infected animals/herds. This should be combined with more government intervention in the areas of regulations and policies concerning routine screening of all cattle populations. Awareness program should be undertaken involving stakeholders in the livestock industry as well as consumers to avert public health, veterinary public health and economic losses associated with tuberculosis.

\section{REFERENCES}

1. Ameni G, Aseffa A, Engers H, Young D, Gordon S, Hewinson G and Vordermeier M (2007). High prevalence and increased severity of pathology of bovine tuberculosis in Holsteins compared to zebu breeds under field cattle husbandry in central Ethiopia. Clinical and Vaccine Immunology 14: 1356-61.

2. Adesokan HK, Ijagbone IF, Oputa HE, Cadmus SIB and Stack JA (2006). Serological survey of brucellosis in livestock animals and workers in Ibadan, southwestern, Nigeria. African Journal of Biomedical Research 9: 163168.

3. Bekele B, Demelash A, Fufa A, Regassa J, Godfroid and Skjerve E (2010). Seroprevalence of brucellosis and its contribution to abortion in cattle, camel, and goat kept under pastoral management in Borana. Tropical Animal Health and Production 43: 651-656.

4. Bermingham ML, More SJ, Good M, Cromie AR, Higgins IM, Brotherstone S and Berry DP (2009). Genetics of tuberculosis in Irish Holstein-Friesian dairy herds. Journal of Dairy Science 92: 3447-3456.

5. Cleaveland S, Shaw DJ, Mfinanga SG, Shirima G, Kazwala RR, Eblate E and Sharp M (2007). Mycobacterium bovis in rural Tahzania: Risk factors for infection in human and cattle populations. Tubercle 87: 30-43.

6. Griffin JF and Mackintosh CG (2000). Tuberculosis in deer: perceptions, problems and progress. The Veterinary Journal 161: 100.

7. Hutchings MR and Harris S (1997). Effects of farm management practices on cattle grazing behavior and the potential for transmission of bovine tuberculosis from badgers to cattle. Veterinary Journal 153: 149-162.

8. Islam MM, Siddique MAR, Haque MA, Baki MA, Majumder S, Parrish JJ and Shamsuddin M (2007). Screening some major communicable diseases of AI bulls in Bangladesh. Livestock Research Rural Development 19: 79.

9. Mathews F, Macdonald DW, Taylor GM, Gelling M, Norman RA, Honess PE, Foster R, Gower CM, Varley S, Harris A, Palmer S, Hewinson G and Webster JP (2006). Bovine tuberculosis (Mycobacterium bovis) in British farmland wildlife: the importance to agriculture. Proceedings Biological Sciences 273: 357-365.

10. Menzies FD and Neill SD (2000). Cattle-to-cattle transmission of bovine tuberculosis. The Veterinary Journal 160: 92-106.

11. OIE (2004). Manual of Standards for Diagnostic Tests and Vaccines of World Organization for Animal Health. $4^{\text {th }}$ edition.

12. Pharo HJ, Motalib A, Routledge SF and Alam S (1981). The prevalence of bovine tuberculosis in the Bangladesh Cattle Development Project. Bangladesh Veterinary Journal 15: 53-56.

13. Phillips CJ, Foster CR, Morris PA and Teverson R (2002). Genetic and management factors that influence the susceptibility of cattle to Mycobacterium bovis infection. Animal Health Research Reviews 3: 3-13.

14. Pollock JM and Neill SD (2002). Mycobacterium bovis infection and tuberculosis in cattle. The Veterinary Journal 163: 115-127.

15. Polyakov VA, Ishekenov MS and Kosenko VI (1994). Flies-one of the links in the transmission mechanism of tuberculosis in animals. Problemy Veterinarnoi Sanitari Ekdojii 93: 84-92.

16. Rahman MM and Samad MA (2008). Prevalence of Bovine tuberculosis and its effects on milk production in Red Chittagong cattle. Bangladesh Journal of Veterinary Medicine 6:175-178.

17. Samad MA and Rahman MS (1986). Incidence of bovine tuberculosis and its effect on certain blood indices in dairy cattle of Bangladesh. Indian Journal of Dairy Science 39: 3 - 6.

18. Samad MA (2008). Animal Husbandry and Veterinary Science. Mymensingh, Bangladesh: $1^{\text {st }}$ Publication LEP Pub No. 11, BAU Campus, Mymensingh. 
19. Sauter CM and Morris RS (1995). Dominance hierarchies in cattle and red deer (Cervuselaphus): their possible relationship to the transmission of bovine tuberculosis. New Zealand Veterinary Journal 43: 301-305.

20. Swai ES , Shirima G, Bwanga S and Moshy W (2006). Bovine tuberculosis survey in urban and peri-urban dairy farms in coastal humid region of Tanga, Tanzania. Bulletin of Animal Health and Production in Africa 54: 75-78.

21. Tahmid U, Akter ASMMR, Nazmunnaher Khatun M, Abdul Mannan M, Mostafizer Rahman M and Lutful Kabir SM (2014). Investigation of Bovine Tuberculosis in Rangpur Division of Bangladesh. Journal of Life Sciences Research 1: 1-4.

22. Vordermeier M, Ameni G and Glass EJ (2011). Cytokine responses of Holstein and Sahiwal zebu derived monocytes after mycobacterial infection. Tropical Animal Health and Production 44: 651-655.

23. World Health Organization, Food and Agriculture Organization of the United Nations \& World Organization for Animal Health (2004). Report of the WHO/FAO/OIE joint consultation on emerging zoonotic diseases, World Health Organization, Geneva. 